\title{
Cellulomonas xylanilytica sp. nov., a cellulolytic and xylanolytic bacterium isolated from a decayed elm tree
}

\author{
Raúl Rivas, Martha E. Trujillo, P. F. Mateos, E. Martínez-Molina \\ and Encarna Velázquez
}

Correspondence

Martha E. Trujillo

mett@usal.es

\begin{abstract}
Departamento de Microbiología y Genética, Edificio Departamental, Campus Miguel de Unamuno, Universidad de Salamanca, Spain
\end{abstract}

\begin{abstract}
A Gram-positive, aerobic, non-motile bacterium was isolated from a decayed elm tree. Phylogenetic analysis based on $16 \mathrm{~S}$ rDNA sequences revealed $99.0 \%$ similarity to Cellulomonas humilata. Chemotaxonomic data that were determined for this isolate included cell-wall composition, fatty acid profiles and polar lipids; the results supported the placement of strain $\mathrm{XIL} 11^{\top}$ in the genus Cellulomonas. The DNA G+C content was $73 \mathrm{~mol} \%$. The results of DNA-DNA hybridization with C. humilata ATCC $25174^{\top}$, in combination with chemotaxonomic and physiological data, demonstrated that isolate $\mathrm{XIL} 11^{\top}$ should be classified as a novel Cellulomonas species. The name Cellulomonas xylanilytica sp. nov. is proposed, with strain XIL11 ${ }^{\top}\left(=\right.$ LMG $21723^{\top}=$ CECT $\left.5729^{\top}\right)$ as the type strain.
\end{abstract}

During a study of bacterial populations that degrade plant polymers, we isolated several bacteria that produced hydrolytic enzymes; isolate XIL11 ${ }^{\mathrm{T}}$ was able to break down several polymers, namely cellulose, starch and xylan. On the basis of $16 \mathrm{~S}$ rDNA sequence data, this strain was characterized primarily as a member of the genus Cellulomonas, which currently contains 14 species with validly published names (Stackebrandt \& Keddie, 1986; Funke et al., 1995; Collins \& Pascual, 2000; Elberson et al., 2000; Stackebrandt et al., 2002). Further study of this strain, based on a polyphasic approach that included chemotaxonomic, physiological and DNA-DNA hybridization analyses, confirmed its position as a representative of a novel species within the genus Cellulomonas.

Strain XIL $11^{\mathrm{T}}$ was isolated on XED medium at $28^{\circ} \mathrm{C}$ from decayed wood of an elm tree, as described previously (Rivas et al., 2003). Extraction and amplification of genomic DNA for $16 \mathrm{~S}$ rDNA sequence analysis were carried out as described previously (Rivas et al., 2001, 2003). An almostcomplete $16 \mathrm{~S}$ rDNA sequence was obtained and aligned against $16 \mathrm{~S}$ rDNA sequences that were available from public databases. Pairwise evolutionary distances were computed by using the correction algorithm of Jukes \& Cantor (1969). The least-squares distance method of DeSoete (1983) was

Published online ahead of print on 17 October 2003 as DOI 10.1099/ ijs.0.02866-0.

The GenBank/EMBL/DDBJ accession number for the $16 \mathrm{~S}$ rDNA sequence of strain XIL $11^{\top}$ is AY303668.

A fuller phylogenetic tree is available as supplementary material in IJSEM Online. used in the construction of the phylogenetic dendrogram from distance matrices. The MEGA2 package (Kumar et al., 2001) was used for all analyses.

Isolate $\mathrm{XIL}_{11}{ }^{\mathrm{T}}$ was observed through a phase-contrast microscope after 48 h growth in YED medium $(0.4 \%$ yeast extract, $0 \cdot 7 \%$ dextrose, $1 \cdot 8 \%$ agar) to check for cell shape and motility. Cells were also stained according to the classical Gram procedure that was described by Doetsch (1981).

Physiological and biochemical tests were determined by using API 20NE, API 20E and API $50 \mathrm{CH}$ strips (bioMérieux) according to the manufacturer's instructions. Enzyme activities for amylase, casein, catalase, cellulase and oxidase were determined as described previously (Rivas et al., 2003). A temperature range for growth on YED medium of $4-45^{\circ} \mathrm{C}$ was determined.

Amino acid and sugar analyses of whole-cell hydrolysates were performed according to procedures described by Staneck \& Roberts (1974). Peptidoglycan type was determined as described by Schleifer \& Kandler (1972) and Schleifer (1985). Menaquinone and cellular fatty acid compositions were determined as described by Zimmermann et al. (1998). Polar lipids were extracted and examined by two-dimensional TLC (Minnikin et al., 1984).

The $\mathrm{G}+\mathrm{C}$ content of genomic DNA was determined by using the thermal denaturation method (Mandel \& Marmur, 1968).

DNA-DNA hybridization was performed [in $2 \times$ SSC $+10 \%$ 
DMSO (v/v) at $68^{\circ} \mathrm{C}$ ] between strain XIL1 $1^{\mathrm{T}}$ and Cellulomonas humilata ATCC $25174^{\mathrm{T}}$. DNA was isolated as described by Cashion et al. (1977). Renaturation rates were calculated by using the TRANSFER.BAS program (Jahnke, 1992).

Strain $\mathrm{XIL}_{1} 1^{\mathrm{T}}$ was characterized morphologically as a Gram-positive, non-filamentous actinomycete that grew as lemon-yellow colonies on XED and YED media. Cells were non-motile and coccoid in shape $(2 \cdot 4 \times 1 \cdot 4 \mu \mathrm{m})$. Details of various differentiating characteristics of strain $\mathrm{XIL}_{1} 1^{\mathrm{T}}$ and phylogenetically related species are shown in Table 1. Other characteristics determined are given in the species description. Isolate $\mathrm{XIL}_{1} 1^{\mathrm{T}}$ grew at $4-37^{\circ} \mathrm{C}$. No growth was recorded at $45^{\circ} \mathrm{C}$.

The 16S rDNA sequence of strain XIL11 ${ }^{\mathrm{T}}$ was obtained and compared with those of members of the genus Cellulomonas. The sequence of strain XIL11 ${ }^{\mathrm{T}}$ showed $99 \cdot 0 \%$ similarity to the $16 \mathrm{~S}$ rDNA sequence of $C$. humilata ATCC $25174^{\mathrm{T}}$. A phylogenetic tree that was obtained by using the leastsquares method shows this close relationship (Fig. 1), which was supported by a high bootstrap value $(100 \%)$ based on 1000 resamplings. A fuller phylogenetic tree is available as supplementary material in IJSEM Online.

The $16 \mathrm{~S}$ rDNA sequence of strain XIL11 ${ }^{\mathrm{T}}$ contained most of the signature nucleotides that have been defined for members of the genus Cellulomonas (Stackebrandt et al., 2002), except for the nucleotides at positions 614-626 (A$\mathrm{U})$ and $1438-1463(\mathrm{~A}-\mathrm{U})$, which were identical to those found in the sequence of $C$. humilata, but differed from those of the rest of the species in the genus Cellulomonas.

The peptidoglycan composition of strain $\mathrm{XIL}_{11}{ }^{\mathrm{T}}$ corresponded to type A4 $\beta$; it contained D-ornithine-D-glutamic acid. This composition is reported for most members of the genus Cellulomonas and has been emphasized as an important feature for delineation at genus level in actinobacteria (Stackebrandt \& Schumann, 2000). In the case of C. humilata ATCC $25174^{\mathrm{T}}$, Gledhill \& Casida (1969) found that the peptidoglycan of this strain contained lysine and ornithine, whereas Stackebrandt et al. (2002) reported Lornithine-D-glutamic acid; the latter composition is found in most Cellulomonas species, including strain XIL11 ${ }^{\mathrm{T}}$. If the peptidoglycan results obtained by Stackebrandt et al. (2002) are confirmed, the genus Cellulomonas would then embrace a homogeneous group with respect to peptidoglycan structure, with L-ornithine in the third position of the peptide side-chain and D-aspartic acid or D-glutamic acid in the interpeptide bridge.

The cell-wall sugars in strain $\mathrm{XIL}_{11}{ }^{\mathrm{T}}$ were rhamnose, mannose and traces of fucose. The major fatty acids were anteiso- $\mathrm{C}_{15: 0}(41 \cdot 66 \%)$, iso- $\mathrm{C}_{16: 0}(13 \cdot 37 \%)$, iso- $\mathrm{C}_{18: 0}$ $(12 \cdot 83 \%)$ and anteiso- $\mathrm{C}_{17: 0}(6 \cdot 87 \%)$. The main difference

Table 1. Characteristics that differentiate C. xylanilytica from phylogenetically related Cellulomonas species

Species: 1, C. xylanilytica; 2, C. humilata; 3, C. biazotea; 4, C. cellasea; 5, C. fimi; 6, C. hominis. +, Positive; -, negative; W, weak; ND, not determined. All strains were positive for fermentation and negative for urea hydrolysis. Data are from Collins \& Pascual (2000), Elberson et al. (2000), Schumann et al. (2001) and this study.

\begin{tabular}{|c|c|c|c|c|c|c|}
\hline Characteristic & 1 & 2 & 3 & 4 & 5 & 6 \\
\hline Shape & $\begin{array}{l}\text { Curved rods } \\
\text { or coccoid }\end{array}$ & $\begin{array}{l}\text { Diphtheroid } \\
\text { or coccoid }\end{array}$ & $\begin{array}{l}\text { Straight or } \\
\text { curved rods }\end{array}$ & $\begin{array}{l}\text { Straight or } \\
\text { curved rods }\end{array}$ & $\begin{array}{l}\text { Straight or } \\
\text { curved rods }\end{array}$ & $\begin{array}{c}\text { Regular } \\
\text { short rods }\end{array}$ \\
\hline Mycelium & - & + & - & - & - & - \\
\hline Motility & - & - & + & - & + & + \\
\hline Catalase & + & - & + & + & + & + \\
\hline \multicolumn{7}{|l|}{ Growth in: } \\
\hline Acetate & - & - & + & + & - & ND \\
\hline Gluconate & - & + & - & - & - & + \\
\hline Lactose & + & + & + & - & + & + \\
\hline Mannitol & - & + & - & + & - & - \\
\hline Rhamnose & + & + & + & - & + & + \\
\hline Hydrolysis of gelatin & $\mathrm{w}$ & W & + & - & + & + \\
\hline Peptidoglycan type & L-Orn-D-Glu & L-Orn-D-Glu $\dagger$ & L-Orn-D-Glu & L-Orn-D-Glu & L-Orn-D-Glu & L-Orn \\
\hline Cell-wall sugars $\ddagger$ & Rha, Man, Fuc & Rha, Glc, Fuc & $\begin{array}{c}\text { Rha, Gal, Man, } \\
\text { 6-deoxy-Tal }\end{array}$ & $\begin{array}{l}\text { Rha, Man, } \\
\text { 6-deoxy-Tal }\end{array}$ & Rha, Fuc, Glc & ND \\
\hline Principal fatty acids & $\begin{array}{c}\text { ai- } C_{15: 0}, C_{16: 0}, \\
C_{18: 0}\end{array}$ & $\mathrm{ND}$ & $\begin{array}{c}\text { ai- } C_{15: 0}, i-C_{15: 0} \\
C_{16: 0}\end{array}$ & $\begin{array}{c}\text { ai- } C_{15: 0}, C_{16: 0} \\
\text { ai- } C_{17: 0}\end{array}$ & $\begin{array}{c}\text { ai- } C_{15: 0}, C_{16: 0} \\
\text { ai- } C_{17: 0}\end{array}$ & $\begin{array}{c}\text { ai- } C_{15: 0}, C_{16: 0}, \\
\text { ai- } C_{17: 0}\end{array}$ \\
\hline
\end{tabular}

${ }^{\star}$ Glu, Glutamic acid; Orn, Ornithine.

$†$ Composition according to Stackebrandt et al. (2002). Lysine and ornithine have been reported by Gledhill \& Casida (1969).

¥Fuc, Fucose; Glc, glucose; Man, mannose; Rha, rhamnose; Tal, talose. 


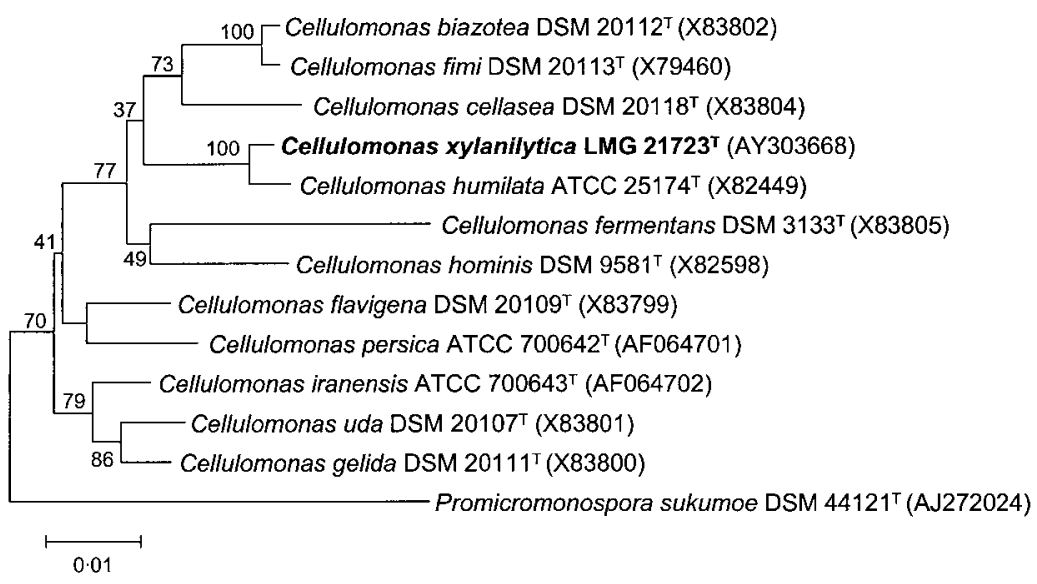

Fig. 1. Dendrogram based on comparison of $16 \mathrm{~S}$ rRNA gene sequences of the proposed species C. xylanilytica XIL $11^{\top}$ and its closest phylogenetic neighbours. Bootstrap values are expressed as percentages of 1000 replications. Bar, 1 substitution in $100 \mathrm{nt}$. was the fairly large amount of $\mathrm{C}_{18: 0}$ in the new isolate with respect to other Cellulomonas species (Schumann et al., 2001).

HPLC analysis of menaquinones revealed two peaks: the main peak corresponded to $\mathrm{MK}-9\left(\mathrm{H}_{4}\right)$ and the smaller one to $\mathrm{MK}-8\left(\mathrm{H}_{4}\right)$. MK-9 $\left(\mathrm{H}_{4}\right)$ is the major menaquinone found in members of the family Cellulomonadaceae. Polar lipids detected were diphosphatidylglycerol, phosphatidylethanolamine, phosphatidylinositol and phosphatidylinositol mannosides.

The results of DNA-DNA hybridization showed $36.6 \%$ relatedness between strain $\mathrm{XIL}_{11}^{\mathrm{T}}$ and $C$. humilata ATCC $25174^{\mathrm{T}}$, suggesting that isolate XIL11 ${ }^{\mathrm{T}}$ should be classified as a novel species, in view of the recommendations of Wayne et al. (1987) for species delineation. The $\mathrm{G}+\mathrm{C}$ content of the DNA of this strain is $73 \mathrm{~mol} \%$, a value that falls within the range reported for other members of the genus. Therefore, on the basis of chemotaxonomic, phylogenetic and physiological data, we propose that isolate $\mathrm{XIL}_{1}{ }^{\mathrm{T}}$ should be classified as the type strain of a novel species, Cellulomonas xylanilytica sp. nov.

\section{Description of Cellulomonas xylanilytica sp. nov.}

Cellulomonas xylanilytica (xy.la.ni.ly'ti.ca. N.L. n. xylan xylan, a plant polymer; N.L. adj. lyticus from Gr. adj. lytos dissolving; N.L. fem. adj. xylanilytica xylan-dissolving).

Gram-positive, non-flagellated, non-spore-forming, coccoid or rod-shaped cells $(2 \cdot 4 \times 1 \cdot 4 \mu \mathrm{m})$. Aerobic or facultatively anaerobic and chemo-organotrophic. Colonies on YED medium are smooth, yellow and usually $1-3 \mathrm{~mm}$ in diameter within 7 days at $28^{\circ} \mathrm{C}$. Aerial mycelium is not formed. Optimal growth temperature is $30^{\circ} \mathrm{C}$. Optimal growth $\mathrm{pH}$ is 7 . Oxidase- and catalase-positive. Phylogenetically related to members of the family Cellulomonadaceae. Utilizes arabinose, cellulose, gentiobiose, maltose, mannose, $\mathrm{N}$-acetylglucosamine, starch and xylan as sole carbon sources. By contrast, no growth occurs in acetate, adipate, caprate, citrate, malate, mannitol, phenylacetate or ribose.
Acid is produced from amygdalin, arbutin, cellobiose, D-fructose, galactose, glucose, glycerol, glycogen, inulin, lactose, D-lyxose, maltose, D-mannose, melezitose, melibiose, D-raffinose, rhamnose, salicin, L-sorbose, sucrose, trehalose, xylitol, D-xylose, methyl $\alpha$-D-glucoside, methyl $\alpha$-D-mannoside, $N$-acetylglucosamine and $\beta$-gentiobiose. Amylases, cellulases, $\beta$-galactosidase and xylanases are actively produced. Aesculin, casein and gelatin are hydrolysed. Nitrate is reduced to nitrite. Arginine dehydrolase, indole, tryptophan deaminase and urease are not produced. Major fatty acids are ai- $\mathrm{C}_{15: 0}, \mathrm{C}_{16: 0}$ and $\mathrm{C}_{18: 0}$. Major isoprenoid quinones are MK-9 $\left(\mathrm{H}_{4}\right)$ and $\mathrm{MK}-8\left(\mathrm{H}_{4}\right)$. Peptidoglycan contains L-ornithine-L-glutamic acid (type $\mathrm{A} 4 \beta$ ). Cell-wall sugars are rhamnose, mannose and fucose.

The type strain is XIL11 ${ }^{\mathrm{T}}\left(=\mathrm{LMG} 21723^{\mathrm{T}}=\mathrm{CECT} 5729^{\mathrm{T}}\right)$.

\section{Acknowledgements}

This work was supported by the Ministerio de Ciencia y Tecnología (CAICYT-DGES) and the Junta de Castilla y León (JCyL, Spanish Government). We thank Dr R. Kroppenstedt and Dr P. Schumann of the Deutsche Sammlung von Mikroorganismen und Zellkulturen GmbH (Braunschweig, Germany) for their help with the chemotaxonomic and DNA-DNA hybridization analyses, respectively. We thank M. Sánchez for help with $16 \mathrm{~S}$ rDNA sequencing.

\section{References}

Cashion, P., Holder-Franklin, M. A., McCully, J. \& Franklin, M. (1977). A rapid method for the base ratio determination of bacterial DNA. Anal Biochem 81, 461-466.

Collins, M. D. \& Pascual, C. (2000). Reclassification of Actinomyces humiferus (Gledhill and Casida) as Cellulomonas humilata nom. corrig., comb. nov. Int J Syst Evol Microbiol 50, 661-663.

DeSoete, G. (1983). A least squares algorithm for fitting additive trees to proximity data. Psychometrika 48, 621-626.

Doetsch, R. N. (1981). Determinative methods of light microscopy. In Manual of Methods for General Bacteriology, pp. 21-33. Edited by P. Gerdhardt, R. G. E. Murray, R. N. Costilow, E. W. Nester, W. A. Wood, N. R. Krieg \& G. B. Phillips. Washington, DC: American Society for Microbiology. 
Elberson, M. A., Malekzadeh, F., Yazdi, M. T., Kameranpour, N., Noori-Daloii, M. R., Matte, M. H., Shahamat, M., Colwell, R. R. \& Sowers, K. R. (2000). Cellulomonas persica sp. nov. and Cellulomonas iranensis sp. nov., mesophilic cellulose-degrading bacteria isolated from forest soils. Int J Syst Evol Microbiol 50, 993-996.

Funke, G., Pascual Ramos, C. \& Collins, M. D. (1995). Identification of some clinical strains of CDC coryneform group A-3 and A-4 bacteria as Cellulomonas species and proposal of Cellulomonas hominis sp. nov. for some group A-3 strains. J Clin Microbiol 33, 2091-2097.

Gledhill, W. E. \& Casida, L. E., Jr (1969). Predominant catalasenegative soil bacteria. II. Occurrence and characterization of Actinomyces humiferus, sp. N. Appl Microbiol 18, 114-121.

Jahnke, K.-D. (1992). Basic computer program for evaluation of spectroscopic DNA renaturation data from GILFORD system 2600 spectrometer on a PC/XT/AT type personal computer. J Microbiol Methods 15, 61-73.

Jukes, T. H. \& Cantor, C. R. (1969). Evolution of protein molecules. In Mammalian Protein Metabolism, pp. 21-132. Edited by H. N. Munro. New York: Academic Press.

Kumar, S., Tamura, K., Jakobsen, I. B. \& Nei, M. (2001). MEGA2: molecular evolutionary genetic analysis software. Bioinformatics 17, $1244-1245$.

Mandel, M. \& Marmur, J. (1968). Use of ultraviolet absorbance temperature profile for determining the guanine plus cytosine content of DNA. Methods Enzymol 12B, 195-206.

Minnikin, D. E., O’Donnell, A. G., Goodfellow, M., Alderson, G., Athalye, M., Schaal, K. \& Parlett, J. H. (1984). An integrated procedure for the extraction of isoprenoid quinones and polar lipids. J Microbiol Methods 2, 233-241.

Rivas, R., Velázquez, E., Valverde, A., Mateos, P. F. \& MartínezMolina, E. (2001). A two primers random amplified polymorphic DNA procedure to obtain polymerase chain reaction fingerprints of bacterial species. Electrophoresis 22, 1086-1089.

Rivas, R., Sánchez, M., Trujillo, M. E., Zurdo-Piñeiro, J. L., Mateos, P. F., Martínez-Molina, E. \& Velázquez, E. (2003). Xylanimonas cellulosilytica gen. nov., sp. nov., a xylanolytic bacterium isolated from a decayed tree (Ulmus nigra). Int J Syst Evol Microbiol 53, 99-103.

Schleifer, K. H. (1985). Analysis of the chemical composition and primary structure of murein. Methods Microbiol 18, 123-156.

Schleifer, K. H. \& Kandler, O. (1972). Peptidoglycan types of bacterial cell walls and their taxonomic implications. Bacteriol Rev 36, 407-477.

Schumann, P., Weiss, N. \& Stackebrandt, E. (2001). Reclassification of Cellulomonas cellulans (Stackebrandt and Keddie 1986) as Cellulosimicrobium cellulans gen. nov., comb. nov. Int J Syst Evol Microbiol 51, 1007-1010

Stackebrandt, E. \& Keddie, R. M. (1986). Genus Cellulomonas. In Bergey's Manual of Systematic Bacteriology, vol. 2, pp. 1325-1329. Edited by P. H. A. Sneath, N. S. Mair, M. E. Sharpe \& J. G. Holt. Baltimore: Williams \& Wilkins.

Stackebrandt, E. \& Schumann, P. (2000). Description of Bogoriellaceae fam. nov., Dermacoccaceae fam. nov., Rarobacteraceae fam. nov. and Sanguibacteraceae fam. nov. and emendation of some families of the suborder Micrococcineae. Int J Syst Evol Microbiol 50, 1279-1285.

Stackebrandt, E., Breymann, S., Steiner, U., Prauser, H., Weiss, N. \& Schumann, P. (2002). Re-evaluation of the status of the genus Oerskovia, reclassification of Promicromonospora enterophila (Jáger et al. 1983) as Oerskovia enterophila comb. nov. and description of Oerskovia jenensis sp. nov. and Oerskovia paurometabola sp. nov. Int J Syst Evol Microbiol 52, 1105-1111.

Staneck, J. L. \& Roberts, G. D. (1974). Simplified approach to identification of aerobic actinomycetes by thin-layer chromatography. Appl Microbiol 28, 226-231.

Wayne, L. G., Brenner, D. J., Colwell, R. R. \& 9 other authors (1987). International Committee on Systematic Bacteriology. Report of the ad hoc committee on reconciliation of approaches to bacterial systematics. Int J Syst Bacteriol 37, 463-464.

Zimmermann, O., Spröer, C., Kroppenstedt, R. M., Fuchs, E., Köchel, H. G. \& Funke, G. (1998). Corynebacterium thomssenii sp. nov., a Corynebacterium with $N$-acetyl- $\beta$-glucosaminidase activity from human clinical specimens. Int J Syst Bacteriol 48, 489-494. 